\section{RPS Brazilian Birth Cohort Consortium (Ribeirão Preto, Pelotas and São Luís): history, objectives and methods}

\author{
Consórcio RPS (Ribeirão Preto, Pelotas e São Luís) \\ de coortes de nascimento brasileiras: história, \\ objetivos e métodos
}

\author{
Consorcio RPS (Ribeirão Preto, Pelotas y São \\ Luís) cohortes brasileñas de nacimiento: \\ historia, objetivos y métodos
}

Susana Cararo

Confortin 1

Marizélia Rodrigues

Costa Ribeiro 1

Aluísio J. D. Barros 2

Ana Maria Baptista

Menezes 2

Bernardo L. Horta 2

Cesar Gomes Victora 2

Fernando C. Barros 3

Helen Gonçalves 2

Heloisa Bettiol 4

Iná Silva dos Santos 2

Marco Antonio Barbieri 4

Maria da Conceição

Pereira Saraiva 4

Maria Teresa Seabra

Soares de Britto e Alves 1

doi: $10.1590 / 0102-311 \times 00093320$

\section{Correspondence \\ S. C. Confortin}

Universidade Federal do Maranhão.

This paper describes the history, objectives and methods used by the nine Brazilian cohorts of the RPS Brazilian Birth Cohorts Consortium (Ribeirão Preto, Pelotas and São Luís). Common thematic axes are identified and the objectives, baseline periods, follow-up stages and representativity of the population studied are presented. The Consortium includes three birth cohorts from Ribeirão Preto, São Paulo State (1978/1979, 1994 and 2010), four from Pelotas, Rio Grande do Sul State (1982, 1993, 2004 and 2015), and two from São Luís, Maranhão State (1997 and 2010). The cohorts cover three regions of Brazil, from three distinct states, with marked socioeconomic, cultural and infrastructure differences. The cohorts were started at birth, except for the most recent one in each municipality, where mothers were recruited during pregnancy. The instruments for data collection have been refined in order to approach different exposures during the early phases of life and their long-term influence on the health-disease process. The investigators of the nine cohorts carried out perinatal studies and later studied human capital, mental health, nutrition and precursor signs of noncommunicable diseases. A total of 17,636 liveborns were recruited in Ribeirão Preto, 19,669 in Pelotas, and 7,659 in São Luis. In the studies starting during pregnancy, 1,400 pregnant women were interviewed in Ribeirão Preto, 3,199 in Pelotas, and 1,447 in São Luís. Different strategies were employed to reduce losses to follow-up. This research network allows the analysis of the incidence of diseases and the establishment of possible causal relations that might explain the health outcomes of these populations in order to contribute to the development of governmental actions and health policies more consistent with reality.

Indicators of Morbidity and Mortality; Noncommunicable Diseases; Cohort Studies; Risk Factors
Rua Barão de Itapary 155, São Luís, MA 65020-070, Brasil. susanaconfortin@gmail.com

1 Universidade Federal do Maranhão, São Luís, Brasil.

2 Universidade Federal de Pelotas, Pelotas, Brasil.

3 Universidade Católica de Pelotas, Pelotas, Brasil.

4 Universidade de São Paulo, São Paulo, Brasil. 


\section{Introduction}

Biological, psychosocial and behavioral processes act in a separate, cumulative or synergic manner since the early phases of life and can operate on a long-term basis in the health-disease process, including subsequent generations 1 . From this perspective, birth cohorts are fundamental for the development of the Epidemiology field since they permit us to establish associations between exposure and the events that follow in the course of life 2,3,4,5,6,7,8.

Cohorts started at birth and followed up along life are of great value by making important contributions to the design of public health policies. Cohort studies started decades ago, with prospectively collected data about life conditions during childhood have been of great interest to public health by permitting to point out childhood living conditions that can affect adult health within a reasonable period of time 2,7. Despite the important contributions originating from these studies in high income countries 9,10,11, birth cohorts in low and middle-income countries are important 12 since, in addition to the assessment of new exposures, certain associations may be modified by the context of the countries 8 .

\section{The Brazilian birth cohorts and the RPS Consortium}

In Brazil, three research groups accompanied nine birth cohorts over a four-decade period. The cohorts involve three municipalities from different regions of the country: Ribeirão Preto (São Paulo State), in the Southeastern region, Pelotas (Rio Grande do Sul State), in the Southern region, and São Luís (Maranhão State), in the Northeastern region 13. The institutions involved are the University of São Paulo, Federal University of Pelotas, and Federal University of Maranhão. These cohorts include individuals born in different years. The first started as a perinatal study about 40 years ago and represents the 1978/1979 Ribeirão Preto cohort. The first Pelotas cohort started in 1982, and the first São Luís cohort started in 1997 13,14,15,16,17,18,19,20.

The data collected at birth at the three sites permitted us to study the health conditions of mothers and their babies, the care provided during the perinatal period according to socioeconomic indicators, and their consequences on infant mortality $13,14,15,16,17,18,19$. The results of these studies also allowed us to determine health transitions and inequalities during periods of economic crisis and after various fiscal adjustment policies in Brazil 13,20,21. Questions were incorporated into the followup questionnaires of these studies in order to assess the repercussions of intrauterine conditions on lifelong growth and development 22,23,24,25,26,27,28,29.

In 2014, with the financial support of the Department of Science and Technology (DECIT) of the Brazilian Ministry of Health, the investigators from the three sites started collaborating to determine differences in health indicators between these three regions. In addition, in order to investigate associations between early exposures and lifelong outcomes, as well as to answer questions about population health that would strengthen the Brazilian Unified National Health System (SUS). This collaboration was named the RPS Brazilian Birth Cohort Consortium (Ribeirão Preto, Pelotas and São Luís) birth cohorts 30,31,32. As such, the purpose of this article is to present the history, the objectives and the methodological designs of the nine cohorts that are part of the RPS Consortium.

\section{The history of the cohorts}

Nine birth cohorts have been set up and followed up thus far in the three cities: Ribeirão Preto (starting years 1978-1979, 1994 and 2010) 13,19,20, Pelotas (1982, 1993, 2004 and 2015) 14,15,16,18,33 and São Luís (1997-1998 and 2010) 17,19. The first studies of Ribeirão Preto and São Luís started as investigations of perinatal health, later transformed into cohort studies. The first Pelotas study (1982) was already started with the objective of following up children during their first years of life.

The objectives of the cohorts were to assess various perinatal health indicators (low birth weight, preterm birth, intrauterine growth restriction, mortality), the use of health services and their association with maternal, biological and socioeconomic variables, and to investigate social inequalities 
in health 13,20. In later follow-ups, the objectives were expanded, including the investigation of early child development and the risk profile for noncommunicable diseases (NCD) and related disorders - obesity, sedentarism, diabetes, metabolic disorders, hypertension, food consumption 24 - and the comparison of various indicators between the cohorts of each city. The last cohort in each city started the recruitment of mothers during pregnancy, instead of immediately after birth. This approach improves the quality of pregnancy data collected and helps assessing factors associated with preterm birth 34 and perinatal health conditions 35 , with emphasis on the identification of risk factors for preterm birth 36 with lifelong implications 19,23,34.

Several new measurements were incorporated or refined into the more recent cohort followups: body composition, bone mineral density, carotid intima thickness, visceral and subcutaneous abdominal fat thickness, oral health (caries, enamel defects and periodontal diseases), lung function, neurocognitive development, social capital, and mental health. Venous blood samples were obtained and stored in a biobank for DNA genotyping and other laboratory tests 26 (EpiGen-Brasil Initiative. EPIGEN-Brazil: the largest Latin America genomic initiative. https://epigen.grude.ufmg.br/, accessed on 09/Dec/2019).

According to the 2010 census (Instituto Brasileiro de Geografia e Estatística. Panorama populacional de Ribeirão Preto. https://cidades.ibge.gov.br/brasil/sp/ribeirao-preto/panorama, accessed on 13/Dec/2019), Ribeirão Preto, with a population of 604,682 inhabitants, had a Municipal Human Development Index (MHDI) of 0.800 and a Gini index of 0.54 (Atlas de Desenvolvimento Humano. Caracterização do território de Ribeirão Preto. http://www.atlasbrasil.org.br/2013/pt/perfil_m/ ribeirao-preto_sp, accessed on 17/Dec/2019). The 2017 infant mortality rate was 9.19 deaths per 1,000 live births (Instituto Brasileiro de Geografia e Estatística. Panorama populacional de Ribeirão Preto. https://cidades.ibge.gov.br/brasil/sp/ribeirao-preto/panorama, accessed on 13/Dec/2019). Pelotas, with 328,275 inhabitants in 2010, had an MHDI of 0.739 (Instituto Brasileiro de Geografia e Estatística. Panorama populacional de Pelotas. https://cidades.ibge.gov.br/brasil/rs/pelotas/ panorama, accessed on 17/Dec/2019) and a Gini index of 0.54 (Atlas de Desenvolvimento Humano. Caracterização do território de Pelotas. http://www.atlasbrasil.org.br/2013/pt/perfil_m/pelotas_rs, accessed on 17/Dec/2019). The 2017 infant mortality rate was 9.98 deaths per thousand live births (Instituto Brasileiro de Geografia e Estatística. Panorama populacional de Pelotas. https://cidades. ibge.gov.br/brasil/rs/pelotas/panorama, accessed on 17/Dec/2019). São Luís, the capital city of Maranhão state, had a population of 1,014,837 inhabitants in 2010, an MHDI of 0.768 (Instituto Brasileiro de Geografia e Estatística. Panorama populacional de São Luís. https://cidades.ibge.gov.br/ brasil/ma/sao-luis/panorama, accessed on 17/Dec/2019). and a Gini index of 0.61 (Atlas de Desenvolvimento Humano. Caracterização do território de São Luís. http://www.atlasbrasil.org.br/2013/ pt/perfil_m/sao-luis_ma, accessed on 17/Dec/2019). The 2017 infant mortality rate was 17.36 deaths per thousand live births (Instituto Brasileiro de Geografia e Estatística. Panorama populacional de São Luís. https://cidades.ibge.gov.br/brasil/ma/sao-luis/panorama, accessed on 17/Dec/2019).

Six of the studies included all liveborns within the reference year 13,14,15,18,19 and three cohorts relied on samples. In the 1994 Ribeirão Preto cohort, data from 1/3 of the births of that year were collected, recruiting births occurring from May to August, since no seasonality in birth distribuition was detected 20,24. In São Luís, 1/7 of births from March 1997 to February 1998, and 1/3 of the 2010 births were selected by systematic sampling 17,19 .

The pioneering investigations in Ribeirão Preto in 1978-1979 13 and of São Luís in 1997-1998 17 were initially planned as cross-sectional perinatal studies, even though their objectives mentioned lifelong repercussions of perinatal and human reproduction questions. All the remaining cohorts were planned from the beginning as longitudinal studies $15,16,18,19,20,36$.

\section{Ribeirão Preto cohorts}

The perinatal study of the first Ribeirão Preto birth cohort was conducted from June 1978 to May 1979 13,20. Registrations and medical records were reviewed in the eight maternities that attended $98 \%$ of all deliveries in the municipality 13 , the puerperal women were interviewed, and the babies were examined ( $n=6,973), 98 \%$ of the liveborns delivered by mothers residing in Ribeirão Preto) 22 . During the subsequent two years, civil registry offices of the city were visited in order to monitor the 
deaths occurring in the first year of life 13. The first follow-up of this cohort happened in 1987/1989, with children sought in schools 23, 2,898 children aged 8 to 11 years 37 were evaluated. In 1996/1997, 2,083 male participants aged 18 to 19 years were evaluated by occasion of military enlistment 23 . Between 2002 and 2004, the cohort was visited again, and 2,103 participants aged 23 to 25 years were evaluated 22. The last follow-up to this cohort occurred in 2016/2017, when 1,775 subjects aged 37 to 39 years were evaluated (Figure 1).

The second Ribeirão Preto cohort included 1/3 of the 1994 births including 2,911 liveborns (99\%) delivered by mothers residing in the municipality 38. In 2004 and 2005, all children of low $(<2,500 \mathrm{~g})$ or high birth weight $(>4,250 \mathrm{~g})$ and one in three children of normal weight were invited to participate. A total of 869 children aged 9 to 11 years were evaluated in this follow-up 38. In 2016, 622 subjects belonging to the original 1994 cohort were evaluated at 22 years of age. In addition, the cohort was opened, with the inclusion of all subjects born in 1994 who had not been enrolled in the initial cohort $(\mathrm{n}=419)$ (Figure 1). The addition of a retrospective component involved the application of some questions of the questionnaire used at birth, whose answers were considered reliable to ask the mother about 20 years later.

Two cohorts were started in 2010, one of them in Ribeirão Preto and the other in São Luís, each consisting of two components: one started during the prenatal period and the other at birth 19,23,34,35,36. The prenatal component of Ribeirão Preto included a convenience sample of 1,400 pregnant women with a singleton pregnancy evaluated at 22 to 25 weeks of gestation. Of these, 1,369 were re-interviewed at the time of childbirth (from April 2010 to June 2011) 34 and 1,081 were investigated during the second year of life of their child. The component that started at birth was population-based and included all infants born from January to December 2010 to mothers residing in the municipality, consisting of 7,752 (95.7\%) liveborns delivered in the municipality of Ribeirão Preto during that year (including 821 children who were evaluated in the prenatal component). The first follow-up occurred from 2011 to 2013 , with 3,807 children followed up during the second and third years of life (Figure 1) 35 .

\section{Figure 1}

Chronology of the nine RPS Consortium Birth Cohort studies. Ribeirão Preto (São Paulo State), Pelotas (Rio Grande do Sul State) and São Luís (Maranhão State), Brazil.

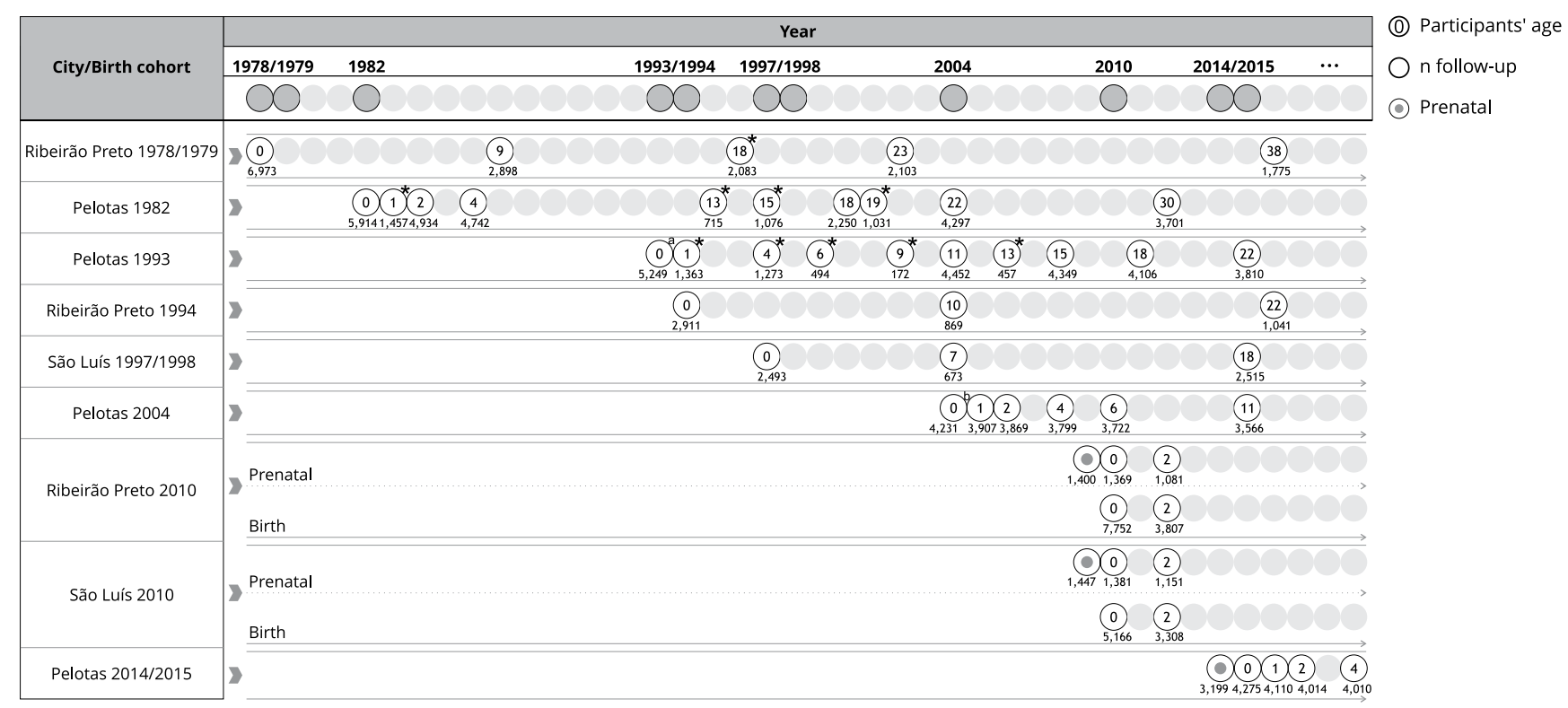

\footnotetext{
* Subsample: (a) Subsample -1 month $(n=649), 3$ months $(n=644), 6$ months $(n=1,414)$; (b) Subsample -3 months $(n=3,985)$.
} 


\section{Pelotas cohorts}

The first birth cohort in the municipality of Pelotas started in January 198214,33 and is already in its tenth follow-up 39. In that study, 5,914 liveborns delivered by mothers residing in the urban zone of Pelotas were recruited and assessed while still in hospital (over 99\% of all births) 25,40,41. After the seventh postpartum day, a representative sample was visited at home in order to assess maternal and infant morbidity and mortality 14 . At 12 months of age, a subsample of 1,457 children was evaluated at home. In 1984, an attempt was made to follow up the entire cohort by means of a census of 60,000 households in Pelotas searching for the children participating in the cohort. A total of 4,934 children (mean age: 19.4 months) were located. An additional follow-up attempting to monitor the entire cohort occurred in 1986, with a new household census that located 4,742 children (mean age: 43.1 months) for evaluation. Further household follow-ups of subsamples occurred in 1995 ( $\mathrm{n}=715), 1997$ ( $\mathrm{n}=1,076)$ and $2001(\mathrm{n}=1,031)$ 25,40, whereas in the year 2000 the male participants were identified and evaluated on occasion of military enlistment $(n=2,250) 25$. The ninth follow-up was held in 2004, when again an attempt was made to follow up the entire cohort, with the evaluation of 4,297 young adults 40 . Until that time, data were collected in the households of the participants. In 2012, when the cohort completed 30 years 39 and the tenth follow-up occurred, data started to be collected at the Federal University of Pelotas Center of Epidemiological Research (CPE, in Portuguese), a center built for the exclusive evaluation of the participants of the Pelotas cohorts 26. On that occasion a considerable effort was made to accompany the entire cohort and 3,701 subjects were interviewed (Figure 1).

The second Pelotas birth cohort started in 1993. All the city hospitals were visited daily and 5,249 (99.7\%) liveborns whose families resided in the urban area of the municipality were examined and their mothers interviewed 27,28. Samples of the participants in the cohort were followed up at $1(\mathrm{n}=$ 649), $3(\mathrm{n}=644), 6(\mathrm{n}=1,414)$ and 12 months $(\mathrm{n}=1,363)$ and at $4(\mathrm{n}=1,273), 6(\mathrm{n}=494), 9(\mathrm{n}=172)$ and $12-13$ years $(n=457) 28$. Visits attempting to follow up all the cohort participants were held in 2004 and 2005, when 4,452 children (mean age: 11 years) were evaluated; in 2008 they were evaluated at 15 years $(n=4,349)$, and then at 18 years $(n=4,106)$ and 22 years $(n=3,810)$ of age. At 15,18 and 22 years of age, the participants were invited to undergo exams at the CPE (Figure 1) 28,31,42,43.

The third Pelotas cohort was started in 2004, when all hospital births were identified, and 4,231 (99.3\%) liveborns were included 18,29. In contrast to the previous ones, the 2004 cohort tried to always accompany all the participants, with follow-ups already performed at 3 ( $\mathrm{n}=3,985), 12$ ( $\mathrm{n}=3,907), 24$ $(\mathrm{n}=3,869)$ and 48 months $(\mathrm{n}=3,799)$ and at $6(\mathrm{n}=3,722) 29$ and 11 years of age $(\mathrm{n}=3,566)$. The 6and 11-year assessments were carried out in a purpose-built clinic annexed to the CPE (Figure 1) 29.

In contrast to the previous birth cohorts, the fourth Pelotas birth cohort, started in 2015, involved a nested prenatal study that interviewed 3,199 pregnant women and identified $98.7 \%$ of the hospital births that occurred between January and December of $2015(\mathrm{n}=4,275)$ 16. So far, the entire cohort has been followed up at $3(n=4,110), 12(n=4,018), 24(n=4,014)$ and $48(n=4,010)$ months of age (Figure 1) 16 .

\section{São Luís cohorts}

The first São Luís cohort included a systematic sample per hospital (1/7 of all births) of 2,493 liveborns in ten maternities in the city from March 1997 to February 1998. In 2005-2006, at 7 to 9 years of age, all children with high or low birth weight and one in three of the normal weight group were invited to participate, with 673 subjects being re-evaluated. In 2016-2017, when the subjects were 18-19 years old, a new attempt was made to evaluate the entire original cohort, with 687 adolescents being evaluated. A retrospective component (with application of a fundamental part of the perinatal questionnaire to mothers of adolescents) was included in this follow-up, consisting of 1,828 adolescents born in São Luís in 1997 who had not participated in the original cohort. The new members were selected by random sampling from the System of Information about Liveborns restricting for children born in 1997. Adolescents identified in schools and universities and by means of the social network were also included. Thus, a total of 2,515 adolescents participated in this follow-up (Figure 1) 44 .

The second São Luís cohort was started in 2010 with two components: one started during the prenatal period with a convenience sample (22 to 25 weeks of gestation) of 1,447 pregnant women 34 
and the other at childbirth 19 . Of these 1,447 subjects, 1,381 were also assessed at birth $(2010 / 2011)$ and 1,151 were re-evaluated in 2012/2013 19,34 (Figure 1).

Regarding the population-based birth component 19 , a systematic sample of $1 / 3$ of the births of this year per maternity was evaluated, representing 5,166 liveborns and corresponding to $89.8 \%$ of the births in the municipality 19. On the occasion of the first follow-up held in 2012-2013, an attempt was made to accompany the entire original cohort, with 3,308 children being evaluated in the second year of life 35 (Figure 1).

Standardized questionnaires were applied to all nine cohorts, with the mother or person responsible being interviewed during the subject's childhood and the child being examined. In the followups during adolescence, a questionnaire was applied to the adolescent and to the mother or person responsible. During later adulthood follow-ups, only the member of the cohort responded to the questionnaires and was examined.

\section{The RPS Consortium}

The successful collaboration between Ribeirão Preto and São Luís, which had been underway for the previous 22 years, was extended to Pelotas with the RPS consortium, established in 2014, and permitted the research groups to carry out joint analyses comparing three different regions of the country.

The RPS Consortium was constituted as a research network to investigate life cycle epidemiology in the three municipalities. A research project, called Lifelong Determinants of Obesity, Precursors of Chronic Diseases, Human Capital and Mental Health, had as its main objectives to investigate precursors of adult NCD, body composition, as well as essential health aspects such as human capital and mental health, relating them to exposures in early life. This project has been financed since its inception by the Brazilian Ministry of Health through the DECIT.

The RPS Consortium also intends to strengthen and expand the network of collaboration among birth cohort studies in Brazil, exploring their potential by gathering information for integrated analysis and by using the cultural and social differences among the cities in order to understand how these aspects are related to the outcomes of interest. To this end, a gamut of questionnaire items and the exams performed on the cohorts are being standardized in order to facilitate future collaboration and comparisons.

The first standardized cohort assessments, already under the RPS Consortium, were conducted in 2015, with a follow-up of the 1993 and 2015 cohorts of Pelotas, and in 2016 and 2017, with the follow-up of adolescents (18 and 19 years) of the 1997/1998 São Luís cohort. This was in addition to the follow-up of young adults (21 and 23 years) of the 1994 Ribeirão Preto cohort and of the middleaged adults of the 1978/1979 Ribeirão Preto cohort (37 to 39 years). Previous data collections were not standardized, with the exception of the 2010 cohorts (from the prenatal and birth component) conducted in Ribeirão Preto and São Luís. The experience gained in the initial cohorts led to improvements in tools and methods for the following cohorts. Thus, some strategies for harmonization of information a posteriori were carried out to make it possible to compare data between studies. Comparison among all cohorts does not occur for all variables due to the heterogeneity of the instruments used. However, some instruments could be standardized in specific periods, even if the same questions have not been used. For example, the physical activity questionnaire and schooling may have their information grouped to allow comparisons between cohorts to be made.

The RPS Consortium allowed a relevant improvement of the standardization in terms of data collection across the studies. An additional goal of the collaboration is to train human resources in the field of lifecycle epidemiology, able to carry out research of high standards and to disseminate knowledge created by the consortium.

\section{The major thematic axes of the RPS Consortium}

In order to achieve all its objectives, one of the important aspects of the RPS Consortium is the existence of common thematic axes. The main ones are the genetic, biological, and behavioral precursors 
of chronic diseases, and the conditions of nutrition, body composition and obesity, mental health, and social capital (Box 1) 26,31. The major objectives of each axis are detailed below.

The main objective of the axis of genetic, biological, and behavioral precursors of chronic diseases is to analyze the impact of these factors on the occurrence of NCD. Genotyping of samples from the cohorts' participants of the three centers is currently being performed, together with collection of biological material, laboratory tests and information about health-related behaviors such as physical activity and sleep. Regarding the nutrition, body composition and obesity axis, the characteristics of food consumption are determinant, together with the distribution of body components, to the prevalence of obesity and its temporal trend, and the factors associated with nutrition in different stages of life.

There is a further axis of mental health and social capital concerning the study of child development, cognitive capacity, noncognitive skills and mental disorders, mainly focusing on social capital, productive capacity, and ability for life in society. We also intend to determine how the parents involve themselves and invest in the education and development of their children, to determine the implication of school in the reduction of disparities in cognitive and noncognitive skills, and the role of social violence in behavior and in mental disorders during different stages of life.

The instruments and questionnaires used to compose each thematic axis were selected because they have been validated for each population, in the Portuguese version, or because there was intention of assessing their validity later. Regarding the mental health and social capital axis, the main instruments used were: the Wechsler Intelligence Scale 45, the Strengths and Difficulties Questionnaire 46, the Development and Well-Being Assessment 47, the Center for Epidemiologic Studies Depression Scale-Revised 48 and the Child Depression Inventory ${ }^{49}$. In the nutrition axis to measure body composition and obesity the main tools were the Food Frequency Questionnaire, the Block Questionnaires and the 24-hour food recall 50. The self-administered physical activity recall checklist 51 and the International Physical Activity Questionnaire 52 were used to assess physical activity. In the maternal health axis the main questionnaires were: the Alcohol Use Disorders Identification Test 53, the Edinburgh Questionnaire 54 and the Experiences of Discrimination instrument 55.

\section{Limitations}

The main challenges faced in birth cohorts are losses due to changes of address and telephone numbers and refusals to continue participating. These could be reduced by continuous contact with research participants, during which detailed contact information about the addresses of family, friends or relatives are requested. In addition, information about their place of work or that of their parents and/or guardians and about whether or not they plan to move to a new house in the near future also should be sought.

Losses and refusals were higher in Ribeirão Preto and São Luís. The cohorts of Pelotas had higher follow-up rates partly because of the city's smaller size and with little outward migration. Also, the risk of violence in Pelotas is smaller compared to the other cities, which makes home visits easier to do and people less concerned to participate. In order to reduce losses and selection bias, multiple strategies were developed such as early scheduling with many date options for interview, transportation allowance, drawing of toys for the children who participated in the follow-ups, among others. Depending on the age, other strategies were implemented to follow the cohorts, such as school records, and search for information about the current address with the former neighbors. Currently, possible selection bias caused by follow-up losses are reduced by inverse probability weighting.

It is worth mentioning the difficulties in financing the first studies, which resulted in intervals of almost 10 years between the follow-ups, especially in Ribeirão Preto and São Luís, which contributed to follow-up losses. The lack of funding for follow-ups prevented long term planning for some time. In order to overcome these difficulties, subsamples were randomly selected from the studied population according to criteria of geoeconomic distribution in the city, as done in Ribeirão Preto in the $1978 / 1979$ cohort at 22-24 years of age 22 . 
Box 1

Common thematic axes and main instruments of the RPS Consortium.

\begin{tabular}{|c|c|c|}
\hline AXES & THEMES & INSTRUMENTS \\
\hline \multirow[t]{15}{*}{ Mental health and social capital } & Family organization & HOME (family environment) \\
\hline & & Questionnaire for the evaluation of family composition \\
\hline & Socioeconomic & Schooling ABEP (economic class) \\
\hline & evaluation & Occupation of the family's head \\
\hline & & Family income \\
\hline & History of morbidities & \\
\hline & Violence & WHO Violence Against Women Questionnaire \\
\hline & & Abuse Assessment Screening \\
\hline & & Conflict Tactics Scales Parent-Child (CTSPC) \\
\hline & Mental health disorders & Wechsler Intelligence Scale (WISC) \\
\hline & and IQ & Strengths and Difficulties Questionnaire (SDQ) \\
\hline & & Development and Well-Being Assessment (DAWBA) \\
\hline & & Mini DSM-5 (dimensional assessment psychopathology) \\
\hline & & CESD-R (depression) \\
\hline & & Child Depression Inventory (CDI) \\
\hline \multirow{10}{*}{$\begin{array}{l}\text { Genetic, biological, and behavioral precursors of chronic } \\
\text { diseases }\end{array}$} & Pulmonary function & Basal spirometry \\
\hline & Atherosclerosis & Carotid ultrasound \\
\hline & Blood pressure & Ambulatory blood pressure monitoring \\
\hline & & Pulse wave velocity \\
\hline & Asthma and allergies & $\begin{array}{l}\text { Questionnaire of the International Study of Asthma and } \\
\text { Allergies in Childhood (ISAAC) }\end{array}$ \\
\hline & Genetic mechanisms of & Collection of biological material \\
\hline & NTCD & DNA extraction \\
\hline & Headache and pain & Migraine \\
\hline & Sleep & Epworth Sleepiness Scale Pittsburgh \\
\hline & & Sleep Quality Index Accelerometer \\
\hline \multirow[t]{10}{*}{ Nutrition, body composition, and obesity } & Diet & Food Frequency Questionnaire (FFQ) \\
\hline & & Block Questionnaires (fat and fiber) \\
\hline & & 24-hour food recall \\
\hline & Anthropometry & $\begin{array}{l}\text { Measurement of weight, height, sitting height, waist } \\
\text { circumference }\end{array}$ \\
\hline & Body composition & DXA (Dual-energy X-ray absoptiometry) \\
\hline & & Bodpod (air displacement plethismography) \\
\hline & & 3D Photonic Scanner \\
\hline & Physical activity & Self-Administered Physical Activity Recall Checklist (SAPAC) \\
\hline & & International Physical Activity Questionnaire (IPAQ) \\
\hline & & Accelerometer \\
\hline Oral health & Physical examination & \\
\hline \multirow[t]{7}{*}{ Maternal health } & Maternal health & Hypertension \\
\hline & & Diabetes \\
\hline & & AUDIT (risk of alcohol abuse) \\
\hline & & Fagerstrom (nicotine dependency) \\
\hline & & Edinburgh Questionnaire (Postpartum \\
\hline & & Depression Scale) \\
\hline & & Experiences of Discrimination \\
\hline
\end{tabular}

ABEP: Brazilian Research Companies Association; AUDIT: Alcool Use Disorders Identification Test; CESD-R: Center for Epidemiologic Studies Depression Scale-Revised; DSM-5: Diagnostic and Statistical Manual of Mental Disorders; HOME: Home Observation Measurement of the Environment WHO: World Health Organization. 


\section{Final considerations}

As a research network, the RPS Consortium is highly relevant on the national scene by permitting the oldest population-based birth cohort studies conducted in Brazil to join efforts in order to answer important public health questions and to determine the challenges faced by the SUS. Among other potentialities, it has permitted the standardization of the instruments and procedures used at the same ages, thus permitting comparisons of contrasting socioeconomic and cultural realities during specific periods of time. It is important to point out that the use of similar collection instruments permits joint analyses, increasing the sample size and power of the study. At the beginning, the cohorts basically used questionnaires and anthropometric evaluations, with follow-up in households or schools and on the occasion of the male participants military enlistment. Over time, the evaluations of each cohort started to be performed in research clinics, involving measurements carried out with more sophisticated equipment such as air displacement plethysmography, carotid ultrasound, spirometry, bone densitometry, accelerometry and photonic scanners. In addition, more in-depth assessment of mental health by means of diagnostic instruments and of cognitive skills, and blood collection for laboratory tests, DNA extraction and genetic analyses started to be performed.

The RPS Consortium allows accompanying health conditions along the life course and in various generations in different regions of the country. This research network permits the analysis of the disease incidence and the establishment of a causal relation between the health outcomes of these different populations, contributing to the advancement of knowledge in the field of life cycle epidemiology and providing more consistent results to be used by policy makers in Brazil. Population studies such as the RPS Consortium cohorts are of great interest for the SUS due to their use of representative samples. In addition, the cohorts of the RPS Consortium were planned and are being implemented using a careful methodology, thus producing valid knowledge about causality relations and the longterm consequences of early exposures.

Studies comparing data obtained at various ages and at different times are important so as to determine the variation of a given outcome over time in different generations. Cohort studies can add knowledge and information that will support the discussion of the transmission of social capital in a transgenerational manner.

The RPS Consortium studies and publications will increase scientific public health knowledge for middle and low-income countries. The expectation is to contribute information that will permit interventions for the promotion of population health, contributing to a more effective action of public health policies within the context of the improvement of SUS in Brazil. 


\section{Contributors}

S. C. Confortin, M. R. C. Ribeiro, V. M. F. Simões and A. A. M. Silva contributed to the study conception and analysis of data, writing of the article and relevant critical review of the intellectual content, as well as contributed to the final approval of the version to be published, being responsible for all aspects of the work in ensuring the accuracy and integrity of any part of the work. A. J. D. Barros, A. M. B. Menezes, B. L. Horta, C. G. Victora, F. C. Barros, H. Gonçalves, H. Bettiol, I. S. Santos, M. A. Barbieri, M. C. P. Saraiva, M. F. Silveira, M. R. Domingues, N. P. Lima, P. R. H. Rocha, R. C. Cavalli and V. C. Cardoso participated in the csutdy onception and project, in the relevant critical review of the intellectual content, as well as contributed to the final approval of the version to be published, being responsible for all aspects of the work in ensuring the accuracy and integrity of any part of the work. M. T. S. S. B. Alves and R. F. L. Batista contributed to the study conception and analysis of data, the writing of the article and the relevant critical review of intellectual content. As well as contributed to the final approval of the version to be published, being responsible for all aspects of the work in ensuring the accuracy and integrity of any part of the work.

\section{Additional informations}

ORCID: Susana Cararo Confortin (0000-00015159-4062); Marizélia Rodrigues Costa Ribeiro (0000-0003-4289-4527); Aluísio J. D. Barros (00000002-2022-8729); Ana Maria Baptista Menezes (0000-0002-2996-9427); Bernardo L. Horta (00000001-9843-412X); Cesar Gomes Victora (00000002-2465-2180); Fernando C. Barros (0000-00015973-1746); Helen Gonçalves (0000-0001-64703352); Heloisa Bettiol (0000-0001-8744-4373); Iná Silva dos Santos (0000-0003-1258-9249); Marco Antonio Barbieri (0000-0001-8060-1428); Maria da Conceição Pereira Saraiva (0000-00016858-7029); Maria Teresa Seabra Soares de Britto e Alves (0000-0002-4806-7752); Mariângela Freitas da Silveira (0000-0002-2861-7139); Marlos Rodrigues Domingues (0000-0002-2503-2944); Natália Peixoto Lima (0000-0002-7181-3717); Paulo Ricardo Higassiaraguti Rocha (0000-00024238-9603); Ricardo Carvalho Cavalli (0000-00015010-4914); Rosângela Fernandes Lucena Batista (0000-0002-1529-0165); Viviane Cunha Cardoso (0000-0002-2677-5600); Vanda Maria Ferreira Simões (0000-0001-8351-1348); Antônio Augusto Moura da Silva (0000-0003-4968-5138).

\section{Acknowledgments}

The studies were funded and/or supported by: Brazilian Association of Collective Health (ABRASCO), Brazilian National Research Council (CNPq), Brazilian Graduate Studies Coordinating Board (CAPES), Department of Science and Technology (DECIT/Brazilian Ministry of Health), State Research Foundations of Rio Grande do Sul State (FAPERGS), Maranhão State (FAPEMA) and São Paulo State (FAPESP), International Development Research Center (IDRC), World Health Organization, Children's Pastorate, PROEX, European Union, Wellcome Trust, International Development Research Center (IDRC), Overseas Development Administration, University Hospital (Federal University of Maranhão) and Foundation for Support to Teaching, Research and Assistance of Hospital das Clínicas, Faculty of Medicine of Ribeirão Preto, University of São Paulo. 


\section{References}

1. Ben-Shlomo Y, Cooper R, Kuh D. The last two decades of life course epidemiology, and its relevance for research on ageing. Int J Epidemiol 2016; 45:973-88.

2. Bertoldi AD, Barros FC, Hallal PRC, Mielke GI, Oliveira PD, Maia MFS, et al. Trends and inequalities in maternal and child health in a Brazilian city: methodology and sociodemographic description of four population-based birth cohort studies, 1982-2015. Int J Epidemiol 2019; 48 Suppl 1:i4-15.

3. Roos LL, Wall-Wieler E. Life course epidemiology: modeling educational attainment with administrative data. PLoS One 2017; 12:e0188976.

4. Bengtsson T, Keilman N. Old and new perspectives on mortality forecasting. Cham: Springer International Publishing; 2019. (Demographic Research Monographs).

5. Cai Y, Shaheen SO, Hardy R, Kuh D, Hansell AL. Birth weight, early childhood growth and lung function in middle to early old age: 1946 British birth cohort. Thorax 2016; 71:916-22.

6. Gluckman PD, Hanson MA, Beedle AS. Early life events and their consequences for later disease: a life history and evolutionary perspective. Am J Hum Biol 2007; 19:1-19.

7. Batty GD, Alves JG, Correia J, Lawlor DA. Examining life-course influences on chronic disease: the importance of birth cohort studies from low- and middle-income countries. An overview. Braz J Med Biol Res 2007; 40:127786.

8. Osler M, Andersen A-MN, Lund R, Batty GD, Hougaard CO, Damsgaard MT, et al. Revitalising the Metropolit 1953 Danish male birth cohort: background, aims and design. Paediatr Perinat Epidemiol 2004; 18:385-94.

9. Boyd A, Golding J, Macleod J, Lawlor DA, Fraser A, Henderson J, et al. Cohort profile: 'the Children of the 90s' - the index offspring of the avon longitudinal study of parents and children. Int J Epidemiol 2013; 42:111-27.

10. Wadsworth M, Kuh D, Richards M, Hardy R. Cohort profile: the 1946 National Birth Cohort (MRC National Survey of Health and Development). Int J Epidemiol 2006; 35:49-54.

11. Connelly R, Platt L. Cohort profile: UK Millennium Cohort Study (MCS). Int J Epidemiol 2014; 43:1719-25.

12. McGowan CC, Cahn P, Gotuzzo E, Padgett D, Pape JW, Wolff M, et al. Cohort Profile: Caribbean, Central and South America Network for HIV research (CCASAnet) collaboration within the International Epidemiologic Databases to Evaluate AIDS (IeDEA) programme. Int J Epidemiol 2007; 36:969-76.

13. Barbieri MA, Gomes UA, Antonio ABF, Bettiol H, Almeida LEA, Silva AAM. Saúde perinatal em Ribeirão Preto, SP, Brasil: a questão do método. Cad Saúde Pública 1989; 5:376-87.
14. Fernando C, Victora CG, Vaughan JP, Vieira A, Júnior L. Saúde perinatal em Pelotas, RS, Brasil: fatores sociais e biológicos. Rev Saúde Pública 1984; 18:301-12.

15. Victora CG, Barros FC, Halpern R, Menezes AMB, Horta BL, Tomasi E, et al. Estudo longitudinal da população materno-infantil da região urbana do Sul do Brasil, 1993: aspectos metodológicos e resultados preliminares. Rev Saúde Pública 1996; 30:34-45.

16. Hallal PC, Bertoldi AD, Domingues MR, Silveira MF, Demarco FF, Silva ICM, et al. Cohort profile: the 2015 Pelotas (Brazil) Birth Cohort Study. Int J Epidemiol 2018; 47:1048-1048h.

17. Silva AAM, Coimbra LC, Silva RA, Alves MTSSB, Lamy Filho F, Lamy ZC, et al. Perinatal health and mother-child health care in the municipality of São Luís, Maranhão State, Brazil. Cad Saúde Pública 2001; 17:1413-23.

18. Barros AJD, Santos IS, Victora CG, Albernaz EP, Domingues MR, Timm IK, et al. Coorte de nascimentos de Pelotas, 2004: metodologia e descrição. Rev Saúde Pública 2006; 40:402-13.

19. Silva AAM, Batista RFL, Simões VMF, Thomaz EBAF, Ribeiro CCC, Lamy Filho F, et al. Changes in perinatal health in two birth cohorts (1997/1998 and 2010) in São Luís, Maranhão State, Brazil. Cad Saúde Pública 2015; 31:1437-50.

20. Bettiol H, Barbieri MA, Gomes UA, Andrea M, Goldani MZ, Ribeiro ERO. Saúde perinatal: metodologia e características da população estudada. Rev Saúde Pública 1998; 32:18-28.

21. Barros FC, Victora CG, Vaughan JP, Tomasi E, Horta BL, Cesar JA, et al. The epidemiological transition in maternal and child health in a Brazilian city, 1982-93: a comparison of two population-based cohorts. Paediatr Perinat Epidemiol 2001; 15:4-11.

22. Barbieri MA, Bettiol H, Silva AAM, Cardoso VC, Simões VMF, Gutierrez MRP, et al. Health in early adulthood: the contribution of the 1978/79 Ribeirão Preto birth cohort. Braz J Med Biol Res 2006; 39:1041-55.

23. Cardoso VC, Simões VMF, Barbieri MA, Silva AAM, Bettiol H, Alves MTSSB, et al. Profile of three Brazilian birth cohort studies in Ribeirão Preto, SP and São Luís, MA. Braz J Med Biol Res 2007; 40:1165-76.

24. Silva AAM, Barbieri MA, Cardoso VC, Batista RF, Simões VM, Vianna EO, et al. Prevalence of non-communicable diseases in Brazilian children: follow-up at school age of two Brazilian birth cohorts of the 1990's. BMC Public Health 2011; 11:486.

25. Victora CG, Barros FC, Lima RC, Behague DP, Gonçalves H, Horta BL, et al. The Pelotas birth cohort study, Rio Grande do Sul, Brazil, 19822001. Cad Saúde Pública 2003; 19:1241-56. 
26. Horta BL, Gigante DP, Gonçalves H, Motta JVS, Mola CL, Oliveira IO, et al. Cohort profile update: the 1982 Pelotas (Brazil) birth cohort study. Int J Epidemiol 2015; 44:441-441e.

27. Victora CG, Hallal PC, Araújo CLP, Menezes AMB, Wells JCK, Barros FC. Cohort profile: the 1993 pelotas (Brazil) birth cohort study. Int J Epidemiol 2008; 37:704-9.

28. Gonçalves H, Wehrmeister FC, Assunção MCF, Tovo-Rodrigues L, Oliveira IO, Murray J, et al. Cohort profile update: the 1993 Pelotas (Brazil) birth cohort follow-up at 22 years. Int J Epidemiol 2018; 47:1389-90e.

29. Santos IS, Barros AJ, Matijasevich A, Zanini R, Chrestani Cesar MA, Camargo-Figuera FA, et al. Cohort profile update: 2004 Pelotas (Brazil) birth cohort study. Body composition, mental health and genetic assessment at the 6 years follow-up. Int J Epidemiol 2014; 43:1437$1437 \mathrm{f}$.

30. Ministério da Saúde. Pesquisa Saúde. http:// pesquisasaude.saude.gov.br/noticiaLerMais. xhtml?id=570 (accessed on Dec/2019).

31. Consórcio Ribeirão Preto, Pelotas e São Luís. Determinantes precoces do processo saúde doença no ciclo vital - uma contribuição das coortes de nascimento. https://institucional. ufpel.edu.br/projetos/id/u948 (accessed on 09/Aug/2018).

32. Coortes RPS. São Luís. http://www.coorte. ufma.br/ (accessed on 09/Feb/2020).

33. Victora CG, Barros FC, Martines JC, Béria JU, Vaughan JP. Estudo longitudinal das crianças nascidas em 1982 em Pelotas, RS, Brasil. Rev Saúde Pública 1985; 19:58-68.

34. Ribeiro MRC, Alves MTSSB, Batista RFL, Ribeiro CCC, Schraiber LB, Barbieri MA, et al. Confirmatory factor analysis of the who violence against women instrument in pregnant women: results from the brisa prenatal cohort. PLoS One 2014; 9:e115382.

35. Silva FS, Queiroz RCS, Branco MRFC, Habenschus MIAT, Scorzafave LG, Saraiva MCP, et al. Foco e cobertura do programa Bolsa Família em crianças das coortes de nascimento BRISA, Ribeirão Preto (São Paulo) e São Luís (Maranhão), Brasil. Cad Saúde Pública 2019; 35:e00159718.

36. Silva AAM, Simões VMF, Barbieri MA, Cardoso VC, Alves CMC, Thomaz EBAF, et al. A protocol to identify non-classical risk factors for preterm births: the Brazilian Ribeirão Preto and São Luís prenatal cohort (BRISA). Reprod Health 2014; 11:79.

37. Tomé FS, Cardoso VC, Barbieri MA, Silva AAM, Simões VMF, Garcia CA, et al. Are birth weight and maternal smoking during pregnancy associated with malnutrition and excess weight among school age children? Braz J Med Biol Res 2007; 40:1221-30.

38. Fabbri CE, Barbieri MA, Silva AAM, Gutierrez MR, Bettiol H, Speciali JG, et al. Maternal smoking during pregnancy and primary headache in school-aged children: a cohort study. Cephalalgia 2012; 32:317-27.
39. Centro de Epidemiologia UFPEL. Pesquisas epidemiológicas: estudo de coorte 1982. http://www.epidemio-ufpel.org.br/site/ content/coorte_1982/index.php (accessed on 14/Nov/2019).

40. Kinalski MA, Cadermatori MG, Horta BL, Correa MB, Demarco FF, Pereira-Cenci T. Common mental disorders and bruxism in adults: a birth cohort study. J Dent 2019; 83:27-32.

41. Victora CG, Barros FC. Cohort profile : the 1982 Pelotas (Brazil) birth cohort study. Int J Epidemiol 2006; 35:237-42.

42. Rodrigues LS, Batista RFL, Simões VMF, Rodrigues MRC, Barbieri MA, Bettiol $\mathrm{H}$, et al. Does height catch-up in schoolchildren have an effect on bone mass in adolescents? Analysis in a Brazilian birth cohort. J Pediatr (Rio J) 2019; 95:607-13.

43. Coelho SJDDAC. Nascimento de parto cesário, depressão e transtorno bipolar em adolescentes de uma coorte de nascimento, São Luís-MA [Masters' Thesis]. São Luís: Programa de Pósgraduação em Saúde Coletiva, Universidade Federal do Maranhão; 2019.

44. Simões VMF, Batista RFL, Alves MTSSB, Ribeiro CCC, Thomaz EBF, Carvalho CA, et al. Saúde dos adolescentes da coorte de nascimentos de São Luís, Maranhão, Brasil, 1997/1998. Cad. Saúde Pública 2020; 36:e00164519.

45. Figueiredo VLM, Pinheiro S, Nascimento E. Teste de inteligência WISC-III adaptando para a população brasileira. Psicol Esc Educ 1998; 2:101-7.

46. Fleitlich B, Cortazar PG, Goodman R. Questionário de Capacidades e Dificuldades (SDQ). Infanto Rev Neuropsiquiatr Infanc Adolesc 2000; 8:44-50.

47. Goodman R, Ford T, Richards H, Gatward R, Meltzer $\mathrm{H}$. The development and well-being assessment: description and initial validation of an integrated assessment of child and adolescent psychopathology. J Child Psychol Psychiatry 2000; 41:645-55.

48. Batistoni SST, Néri AL, Cupertino AP. Validade e confiabilidade da versão brasileira da Center for Epidemiological Scale - Depression (CES-D) em idosos brasileiros. Psico USF 2010; 15:13-22.

49. Coutinho MPL, Carolino ZCG, Medeiros ED. Inventário de Depressão Infantil (CDI): evidências de validade de constructo e consistência interna. Aval Psicol 2008; 7:291-300.

50. Pereira RA, Sichieri R. Métodos em epidemiologia nutricional. In: Kac G, Sichieri R, Gigante DP, organizadores. Epidemiologia nutricional. Rio de Janeiro: Editora Fiocruz/Atheneu; 2007. p. 181-200.

51. Farias Júnior JC, Lopes AS, Mota J, Santos MP, Ribeiro JC, Hallal PC. Validade e reprodutibilidade de um questionário para medida de atividade física em adolescentes: uma adaptação do Self-Administered Physical Activity Checklist. Rev Bras Epidemiol 2012; 15:198-210. 
52. Craig CL, Marshall AL, Sjöström M, Bauman AE, Booth ML, Ainsworth BE, et al. International Physical Activity Questionnaire: 12 -country reliability and validity. Med Sci Sports Exerc 2003; 35:1381-95.

53. Moretti-Pires RO, Corradi-Webster CM. Adaptação e validação do Alcohol Use Disorder Identification Test (AUDIT) para população ribeirinha do interior da Amazônia, Brasil. Cad Saúde Pública 2011; 27:497-509.
54. Cox JL, Chapman G, Murray D, Jones P. Validation of the Edinburgh Postnatal Depression Scale (EPDS) in non-postnatal women. J Affect Disord 1996; 39:185-9.

55. Fattore GL, Teles CA, Santos DN, Santos LM, Reichenheim ME, Barreto ML. Validade de constructo da escala Experiences of Discrimination em uma população brasileira. Cad Saúde Pública 2016; 32:e00102415. 


\section{Resumo}

$O$ artigo descreve a história, objetivos e métodos utilizados pelas nove coortes do Consórcio RPS de Coortes de Nascimento. São identificados eixos temáticos comuns, com apresentação dos objetivos, anos de linha de base, fases de seguimento e representatividade das populações de estudo. O Consórcio inclui três coortes de nascimento de Ribeirão Preto, Estado de São Paulo (1978/1979, 1994 e 2010), quatro de Pelotas, Estado do Rio Grande do Sul (1982, 1993, 2004 e 2015) e duas de São Luís, Estado do Maranhão (1997 e 2010). As coortes provêm de três regiões do Brasil, de três estados diferentes, com importantes diferenças socioeconômicas, culturais e de infraestrutura. As coortes foram iniciadas ao nascer dos participantes, exceto a mais recente em cada município, onde as mães foram recrutadas durante a gestação. Os instrumentos para a coleta de dados foram refinados para aproximar diferentes exposições na primeira infância e a influência, a longo prazo, no processo saúde-doença. Os investigadores das nove coortes realizaram estudos perinatais e depois examinaram o capital humano, saúde mental, nutrição e sinais percursores de doenças crônicas. Um total de 17.636 nascidos vivos foram recrutados em Ribeirão Preto, 19.669 em Pelotas e 7.659 em São Luis. Nas coortes que foram iniciadas durante a gestação, foram entrevistadas 1.400 gestantes em Ribeirão Preto, 3.199 em Pelotas e 1.447 em São Luís. Foram utilizadas diferentes estratégias para reduzir as perdas de seguimento. A rede de pesquisa do Consórcio permite analisar a incidência de doenças e identificar possíveis relações causais que podem explicar os desfechos de saúde nessas populações e contribuir para o desenvolvimento de medidas públicas e políticas de saúde que estejam mais de acordo com as respectivas realidades.

Indicadores de Morbimortalidade; Doenças Não Transmissíveis; Estudos de Coortes; Fatores de Risco

\section{Resumen}

El trabajo describe la historia, objetivos y métodos usados por nueve cohortes brasileñas del RPS Consorcio de Cohortes de Nacimiento. Se identificaron los ejes temáticos comunes y los objetivos, así como los periodos de referencia, la presentación del estadio de seguimiento y representatividad de la población estudiada. El consorcio incluye tres cohortes de nacimiento de Ribeirão Preto, Estado de São Paulo (1978/1979, 1994 y 2010), cuatro de Pelotas, Estado del Rio Grande do Sul (1982, 1993, 2004 y 2015), y dos de São Luís, Estado del Maranhão (1997 y 2010). Las cohortes cubren tres regiones de Brasil, de tres estados distintos, con marcadas diferencias socioeconómicas, culturales $y$ de infraestructura. Las cohortes comenzaron con el nacimiento, excepto para la más reciente en cada municipio, donde las madres fueron reclutadas durante la gestación. Los instrumentos para la recogida de datos han sido depurados, con el fin de realizar una aproximación a diferentes exposiciones durante las fases tempranas de la vida y su influencia a largo plazo en el proceso de salud-enfermedad. Se incluyeron a los investigadores de las nueve cohortes, donde se llevaron a cabo estudios perinatales, así como los recursos humanos analizados posteriormente, al igual que la salud mental, nutrición y signos precursores de enfermedades no comunicables. Un total de 17.636 nacidos vivos fueron reclutados en Ribeirão Preto, 19.669 en Pelotas, y 7.659 en São Luís. En los estudios que comenzaron durante el embarazo, 1.400 mujeres embarazadas fueron entrevistadas en Ribeirão Preto, 3.199 en Pelotas, y 1.447 en São Luis. Se usaron diferentes estrategias para reducir pérdidas, con el fin de realizar el seguimiento. Esta red de investigación permite el análisis de la incidencia de enfermedades y el establecimiento de posibles relaciones causales que podrían explicar los resultados de salud de estas poblaciones, con el fin de contribuir al desarrollo de acciones gubernamentales y politicas de salud más consistentes con la realidad.

Indicadores de Morbimortalidad; Enfermedades No Transmisibles; Estudios de Cohortes; Factores de Riesgo
Submitted on 28/Apr/2020

Final version resubmitted on 14/Aug/2020

Approved on 20/Aug/2020 